Journal of Systems Science and Information

Dec., 2021, Vol. 9, No. 6, pp. 608-626

DOI: $10.21078 /$ JSSI-2021-608-19

\title{
Dynamic Evaluation and Analysis of Regional Innovation Capability in Eastern China from the Perspective of High-quality Development
}

\author{
Linming XU \\ School of Management, Fujian University of Technology, Fuzhou 350118, China \\ E-mail:68224233@qq.com \\ Jincheng LU \\ School of Economics and Management, Fuzhou University, Fuzhou 350108, China \\ E-mail: 418992294@qq.com \\ Meijuan LI \\ School of Economics and Management, Fuzhou University, Fuzhou 350108, China; Funding for \\ Research Center of Fujian Economic High Quality Development Based on Social Science Planning of \\ Fujian Province in China, Fuzhou 350108, China \\ E-mail: 758300@qq.com \\ Lerong HE \\ School of Business Administration and Economics, State University of New York at Brockport, \\ Brockport 14420, USA \\ E-mail: lhe@brockport.edu
}

\begin{abstract}
The economy of China has turned to the stage of high-quality development. In this sense, the connotation of regional innovation capacity should reflect more aspects, such as better economic effectiveness, people-centered philosophy of development and better living conditions. This study aims at establishing the evaluation index system of regional innovation capacity under high-quality perspective. Then the dynamic evaluation method based on gray correlation degree and TOPSIS is improved. And the improved method is applied to evaluate the regional innovation capacity under high-quality development perspective. The results show that: 1) The regional innovation capacity of Jiangsu, Zhejiang, Shanghai and Guangdong under high-quality development perspective is better than other regions, while the regional innovation capacity of Beijing-Tianjin-Hebei is imbalanced. Regional innovation capability of Fujian, Shandong, and Hainan from a high-quality perspective is at the middle and lower levels. 2) From the perspective of development trends, the gap of regional innovation capacity between Beijing, Jiangsu, Zhejiang, Shanghai, Guangdong and Fujian, Hebei, Shandong is gradually narrowing. 3) An in-depth analysis of the regional innovation capability of the eastern provinces and cities from the perspective of high-quality development through different dimensions shows that Beijing, Guangdong, Jiangsu perform well in all dimensions, while Fujian and Hainan need to pay more attention to innovation input and the creation of a better innovation environment to enhance innovation output and
\end{abstract}

Received June 23, 2021, accepted October 19, 2021

Supported by the National Science Foundation of China (71872047), Innovation Strategy Research Plan of Fujian Province (2021R0077) 
promote innovation effectiveness. At last, based on above analysis, relevant policy recommendations are proposed.

Keywords regional innovation capability; high-quality development; TOPSIS; gray correlation degree; dynamic evaluation method

\section{Introduction}

The report of the 19th National Congress of the Communist Party of China pointed out that China's economy has shifted from a stage of high-speed growth to a stage of high-quality development, and it is in a critical period of transforming development mode, optimizing economic structure, and transforming growth momentum ${ }^{[1,2]}$. Since the reform and opening up, China's economic development has made tremendous achievements. So far, China's total economic output has become the second largest in the world. However, the rapid economic growth in the past 40 years has been achieved by relying more on factor input and excessive consumption of resources and environment, and some problems that have been constantly exposed, such as high investment in resource factors, but poor development quality and benefits; serious damage to the ecological environment, excessive consumption of resources, etc. ${ }^{[3]}$. These problems show that the high-speed economic development mode that relied on factor input and environmental resource consumption in the past few decades is no longer suitable for China's development. With the growth of the national economy and changes in the characteristics of the development stage, China has entered a new era of high-quality development. High-quality development contains the five new development concepts of innovation, coordination, greenness, openness, and sharing. Innovation is the driving force and the fundamental strategy for high-quality economic development. From the perspective of high-quality development, the ultimate goal of innovation is to achieve more coordinated development; the fruits of development are shared by the people; the ecological environment and people's living quality are improved, rather than simply reflecting the increase in the number of invention patents and scientific papers ${ }^{[4]}$. Therefore, from the perspective of high-quality development, regional innovation capability should have richer connotations.

As a direct driving force for high-quality development, regional innovation capability has always been the core issue of academic research. Existing researches on regional innovation capability mostly focuses on the influencing factors of regional innovation capability, evaluation of regional innovation capability and regional innovation efficiency. In terms of analyzing the influencing factors of regional innovation capability, scholars mainly explored the influence of factors such as OFDI ${ }^{[5]}$, the flow of innovation elements ${ }^{[6]}$, foreign direct investment ${ }^{[7,8]}$, $\mathrm{R} \mathrm{D}^{[9]}$, human resources ${ }^{[10]}$, element agglomeration ${ }^{[11,12]}$, technology factors ${ }^{[13,14]}$, government investment ${ }^{[15]}$ and the accumulation of factors under environmental constraints on regional innovation capability. Through the analysis of the above research, the existing literature usually uses a single index such as new product sales revenue, the number of invention patents or comprehensive index to characterize regional innovation capability. Obviously, with the gradual enrichment of innovation capability and the requirements for high-quality development, a single indicator is no longer sufficient to fully characterize regional innovation capability, and the establishment of a comprehensive evaluation index system can better reflect regional innovation 
capability under the requirements of high-quality development. Regarding the research on regional innovation capability evaluation, the existing literature mainly constructs an evaluation index system from the aspects of innovation input, innovation output, collaborative innovation capability, and economic foundation, so as to realize comprehensive evaluation and analysis of regional innovation capability from a multi-dimensional perspective ${ }^{[16]}$. In terms of regional innovation efficiency research, the main research is the promotion and inhibition of different influencing factors on regional innovation efficiency ${ }^{[17,18]}$.

According to previous studies, the definition of regional innovation capability is mostly limited to factors directly related to regional innovation capability, and high-quality development reflects the new development concepts and provides effective supply. Therefore, the regional innovation capability from the perspective of high-quality development should have richer connotations, instead of just focusing on regional talent capital, intellectual capital, invention patents, scientific papers and sales revenue of new products, and other factors directly related to innovation. It should also reflect the quality and efficiency of innovation, the protection of ecological environment, people's quality of life and other content that reflects high-quality development. There are few researches that evaluate regional innovation capability based on the perspective of high-quality development, most studies mainly focus on the evaluation and analysis of factors directly related to regional innovation capability, but the direction and goals pursued by the economic and social development to a certain stage and requirements will change. As our country enters a new era, regional innovation capability should have richer connotations, so as to be more in line with the meaning of high-quality development.

Regarding the research methods of regional innovation, the statistical analysis methods such as regression analysis ${ }^{[19]}$, dimensionality reduction, and classification analysis are used to study the influencing factors of regional innovation capability and performance. Data envelopment analysis (DEA) and stochastic frontier analysis (SFA) are used to study the eco-efficiency ${ }^{[20]}$ and performance evaluation of the regional innovation system ${ }^{[21]}$. However, in the process of using regression analysis to research regional innovation capability, there may be endogenous problems caused by mutual causality or reverse causality, ignoring important variables and measurement errors ${ }^{[22]}$. Although with the continuous in-depth research of scholars, these problems can be avoided through specific inspection methods and correction of the model, but the calculation process will be more complicated compared to other methods. In addition, factor analysis and principal component analysis both transform a large number of relevant indicators into a few representative indicators through dimensionality reduction. However, in the process of dimensionality reduction, important information may be lost, thereby affecting the accuracy of the evaluation results ${ }^{[23]}$. DEA and other methods can measure the efficiency of regional innovation, but it cannot conduct a detailed analysis of the influencing factors of performance. From the perspective of high-quality development, the connotation of regional innovation capability is richer, and it is necessary to comprehensively consider multiple attributes to evaluate and analyze it from different perspectives. Therefore, in order to comprehensively reflect regional innovation capability based on multiple attributes and avoid inaccurate evaluation results caused by relatively single indicators, it is necessary to adopt a multi-attribute evaluation method to comprehensively evaluate and analyze it from a broader overall perspective. TOPSIS was pro- 
posed by Hwang and Yoon ${ }^{[24]}$, due to its clear logic and simple calculation; it has been widely used in many fields ${ }^{[25]}$ and improved by many researchers ${ }^{[26,27]}$. When using TOPSIS, the data should be preprocessed firstly, and then the positive and negative ideal solutions of each index are determined and the distance between each alternative and the positive and negative ideal solutions is calculated. Finally, the relative closeness of each alternative is obtained to rank all alternatives.

However, TOPSIS also has some shortcomings. TOPSIS can only reflect the distance relationship between data sequences, but cannot reflect the change of curve similarity. While the gray correlation degree ${ }^{[28]}$ reflects the change of curve similarity, and cannot reflect the position relationship. The combination of gray correlation degree and TOPSIS can make up for the above shortcomings to a certain extent ${ }^{[29]}$, which is able to reflect the similarity of distance relationship and curve change between each evaluated object and positive and negative ideal solution at the same time. Moreover, the evaluation results based on TOPSIS cannot reflect the development trend of multiple evaluation objects in a certain period of time. In actual management and decision-making, such problems are often encountered: It is not only necessary to comprehensively compare the development status of evaluation objects at a certain moment ${ }^{[30]}$. The development status also requires a comprehensive comparison of the development status of each evaluated object at different times, as well as the overall status of each evaluated object over a period of time. Therefore, it is necessary to consider the time dimension for dynamic evaluation, analyze the development trend of the evaluated object, which reflect the overall development level of the evaluated object. Therefore, the relative closeness of dynamic evaluation method based on TOPSIS and gray correlation degree proposed by $\mathrm{Wu}$, et al. ${ }^{[31]}$ is introduced to assess the performance of regional innovation capability in eastern China; this method can reflect the distance relationship and the change of curve similarity between each evaluated object and positive and negative ideal solution, simultaneously.

This paper differs from existing related studies and makes the following main contributions to the current literature: First, this article constructs an evaluation index system from the perspective of high-quality development, which involves the contents of ecological environment and people's quality of life compared to previous studies. Second, the relative closeness of dynamic evaluation method based on TOPSIS and gray correlation degree ${ }^{[31]}$ is improved to make it more reasonable. And then, the improved method is used to conduct a dynamic comprehensive evaluation of innovation capabilities of eastern China from the perspective of high-quality development during 2014-2017. According to the in-depth analysis of evaluation results, the strengths and weaknesses of regional innovation capability from the perspective of high-quality development in eastern region are discussed. Finally, the targeted suggestions for the government's policy formulation are put forward.

\section{Evaluation Index System of Regional Innovation Capability from the Perspective of High-quality}

\subsection{The Connotation of High-quality Development}

Grasping the connotation of high-quality development accurately is the basis for scientifically constructing the evaluation index system of regional innovation capability. High-quality 
development embodies the development concept of innovation, coordination, green, openness, and sharing. Innovation, as a driving force leading to economic development, determines the quality, efficiency and sustainability of development; coordination makes the industrial structure, supply structure, and regional development more balanced; green is to further emphasize the importance of natural resources and ecological environment; opening up urges China to actively participate in the development of economic globalization and jointly build a community with a shared future for mankind; sharing is the starting point and goal of development, emphasizing that the achievements of reform and development in the new era are shared by all, so as to meet the needs of the people for a better life. Under the requirements of high-quality development, innovation is not only to improve the output of patents, scientific papers and emerging technologies in a narrow sense, but also to return to the ultimate goal of development, that is, whether the benefits are improved and the people's lives, whether the quality is improved, whether human and nature coexist in harmony, etc. Therefore, these contents should be reflected in the regional innovation capability from the perspective of high-quality development.

Innovation is the first driving force for development, talents are the source of innovation, and innovation subjects and talents are the direct driving force for improving effective supply capabilities. Moreover, the regional economic foundation and the government's support for innovation will also affect the regional innovation capability ${ }^{[2]}$. When the regional economy is more developed, both the regional infrastructure and the investment in innovation will be better than those in relatively backward areas. Similarly, when the regional government supports innovation more strongly, innovation entities such as enterprises, universities, and scientific research institutions will be more enthusiastic about innovation. Therefore, this article takes innovation input and innovation output as the two dimensions of the evaluation index system, including the Full-time Equivalent of R\&D Personal ( $Z_{1}, 10000$ man-years), Number of people with higher education per 10,000 urban employees $\left(Z_{2}\right.$, persons), Internal Expenditure on R\&D $\left(Z_{3}, 100\right.$ million yuan), and Expenditure on Science and Technology in the General Public Expenditure of the Government $\left(Z_{4}, 100\right.$ million yuan), Regular Higher Education Institutions $\left(Z_{5}\right.$, unit), Number of High-tech Enterprises $\left(Z_{6}\right.$, unit), and Number of Industrial Enterprises above Designated Size with R\&D Institutions $\left(Z_{7}\right.$, unit) are used as innovation inputs; Number of Invention Patents per 10,000 people $\left(Z_{8}\right.$, piece), Form Industry or National Standard Items $\left(Z_{9}, \text { item }\right)^{[16]}$, Number of Foreign Scientific Papers $\left(Z_{10}\right.$, piece), Transaction Value in Technical Markets $\left(Z_{11}, 100\right.$ million yuan) and Sales Revenue of New Products $\left(Z_{12}, 100\right.$ million yuan) as the innovation output ${ }^{[16]}$; take Per Capita GDP $\left(Z_{13}, 10\right.$ thousand yuan) and Government Revenue $\left(Z_{14}, 100\right.$ million yuan) as the economic foundation. Enterprise R\&D comes from Government Funds $\left(Z_{15}, 100\right.$ million yuan), Intramural Expenditures on R\&D in Higher Education comes from Government Funds $\left(Z_{16}, 100\right.$ million yuan), and Intramural Expenditure on R\&D of $\mathrm{R} \& \mathrm{D}$ Institutions comes from Government Funds $\left(Z_{17}, 100\right.$ million yuan) as government innovation incentives.

High-quality development is more efficient and sustainable development. With the strengthening of domestic resource and environmental constraints, the demographic dividend has gradually disappeared, and the cost of labor and other factors has continued to rise. The extensive 
development model that relied on a large number of factor inputs, excessive consumption of resources, and high pollution of the ecological environment in the past has been unsustainable. High-quality development is to improve the efficiency of input and output, reduce energy and environmental costs, thereby improving people's living standards and meeting people's needs for a better life. At the same time, talents, as the source of innovation and the core driving factor to achieve high-quality development, will take the regional ecological environment and livability as important reference factors for the foothold. Therefore, from the perspective of green development and attracting talents, ecological environment and livability are both very important components for regional innovation capability. According to above analysis, this paper uses Per Capita Area of Parks and Green Land $\left(Z_{18}\right.$, Sq.m), Per capita emissions of main Pollutant Contents Discharged $\left(Z_{19}\right.$, tons) and International Trade in Goods $\left(Z_{20}\right.$, Trillion yuan) to reflect the regional innovation environment; uses social labor productivity $\left(Z_{25}\right.$, 100 Million yuan), GDP per unit area $\left(Z_{26}, 10\right.$ thousand yuan/mu), Per Capita Disposable Income of Household $\left(Z_{27}\right.$, yuan) and Energy Intensity of $\operatorname{GDP}\left(Z_{28} \text {, tce/10000 yuan }\right)^{[33]}$ to reflect the effectiveness of regional innovation.

High-quality development pays more attention to the openness and results-sharing. Openness and cooperation is the only way to achieve high-quality development. It is an indispensable part of improving China's high-quality development capabilities. The quality of foreign cooperation must be fully improved, and the global quality and high-quality public product supply must be actively participated. Through openness and cooperation, the introduction of foreign capital is conducive to enhancing regional innovation capability. With a high degree of openness, regional enterprises can strengthen exchanges and cooperation with foreign enterprises, digest and absorb their advanced technologies, so as to enhance regional innovation capability ${ }^{[34]}$. The improvement of people's living standards and the sharing of development results are the starting point and end point of high-quality development. The importance of social welfare and education as an integral part of shared development results is an important factor in attracting talents, and it is also a manifestation of people's sense of gain and happiness. Therefore, in this paper, Total Amount of Foreign Investment Actually Utilized ( $Z_{21}$, USD 100 million), The Number of Health Care Institutes $\left(Z_{22}\right.$, unit), Collections of Public Libraries Per Person $\left(Z_{23}\right.$, copy) and Expenditure for Education in the General Public Expenditure of the Government $\left(Z_{24}, 100\right.$ Million yuan) are used to reflect the level of regional openness and the degree of achievement sharing.

According to the aforementioned description of high-quality development, this article starts from clarifying the connotation of high-quality development, and follows the principles of scientificity and objectivity, simplicity and systemic, feasibility and comparability, representativeness and guidance, purpose and dynamics. By referring to existing literature, a relatively comprehensive evaluation index system has been constructed from the four dimensions of regional innovation input, regional innovation output, regional innovation environment, and regional innovation effectiveness. The four dimensions interact and influence each other to form a closely connected organic whole (shown in Table 1). 
Table 1 Evaluation index system

\begin{tabular}{|c|c|c|c|c|c|}
\hline $\begin{array}{l}\text { First } \\
\text { order index }\end{array}$ & $\begin{array}{l}\text { Second } \\
\text { order index }\end{array}$ & $\begin{array}{l}\text { Third } \\
\text { order index }\end{array}$ & Unit & Code & Type \\
\hline \multirow{7}{*}{$\begin{array}{l}\text { Regional } \\
\text { innovation } \\
\text { input }\end{array}$} & \multirow[t]{2}{*}{$\begin{array}{l}\text { Talent } \\
\text { input }\end{array}$} & $\begin{array}{l}\text { Full-time equivalent } \\
\text { of R\&D personal }\end{array}$ & $\begin{array}{l}1000 \\
\text { man-years }\end{array}$ & $Z_{1}$ & + \\
\hline & & $\begin{array}{l}\text { Number of people } \\
\text { with higher education } \\
\text { per } 10,000 \text { urban } \\
\text { employees }\end{array}$ & persons & $Z_{2}$ & + \\
\hline & \multirow[t]{2}{*}{ Funding } & $\begin{array}{l}\text { Internal expenditure } \\
\text { on } R \& D\end{array}$ & $\begin{array}{l}100 \\
\text { million yuan }\end{array}$ & $Z_{3}$ & + \\
\hline & & $\begin{array}{l}\text { Expenditure on science } \\
\text { and technology in the } \\
\text { general public expenditure } \\
\text { of the government }\end{array}$ & $\begin{array}{l}100 \\
\text { million yuan }\end{array}$ & $Z_{4}$ & + \\
\hline & \multirow{3}{*}{$\begin{array}{l}\text { Innovation } \\
\text { subject }\end{array}$} & $\begin{array}{l}\text { Regular higher } \\
\text { education institutions }\end{array}$ & unit & $Z_{5}$ & + \\
\hline & & $\begin{array}{l}\text { Number of } \\
\text { high-tech enterprises }\end{array}$ & unit & $Z_{6}$ & + \\
\hline & & $\begin{array}{l}\text { Number of } \\
\text { industrial enterprises } \\
\text { above designated size } \\
\text { with R\&D institutions }\end{array}$ & unit & $Z_{7}$ & + \\
\hline \multirow{5}{*}{$\begin{array}{l}\text { Regional } \\
\text { innovation } \\
\text { output }\end{array}$} & \multirow[t]{2}{*}{$\begin{array}{l}\text { Knowledge } \\
\text { output }\end{array}$} & $\begin{array}{l}\text { Number of } \\
\text { invention patents } \\
\text { per } 10,000 \text { people }\end{array}$ & piece & $Z_{8}$ & + \\
\hline & & $\begin{array}{l}\text { Form industry or } \\
\text { national standard items }\end{array}$ & item & $Z_{9}$ & + \\
\hline & \multirow{2}{*}{$\begin{array}{l}\text { Technical } \\
\text { output }\end{array}$} & $\begin{array}{l}\text { Number of foreign } \\
\text { scientific papers }\end{array}$ & piece & $Z_{10}$ & + \\
\hline & & $\begin{array}{l}\text { Transaction value } \\
\text { in technical markets }\end{array}$ & $\begin{array}{l}100 \\
\text { million yuan }\end{array}$ & $Z_{11}$ & + \\
\hline & $\begin{array}{l}\text { Income } \\
\text { output }\end{array}$ & $\begin{array}{l}\text { Sales revenue } \\
\text { of new products }\end{array}$ & $\begin{array}{l}100 \\
\text { million yuan }\end{array}$ & $Z_{12}$ & + \\
\hline
\end{tabular}


Table 1 (continued)

\begin{tabular}{|c|c|c|c|c|c|}
\hline $\begin{array}{l}\text { First } \\
\text { order index }\end{array}$ & $\begin{array}{l}\text { Second } \\
\text { order index }\end{array}$ & $\begin{array}{l}\text { Third } \\
\text { order index }\end{array}$ & Unit & Code & Type \\
\hline \multirow{12}{*}{$\begin{array}{l}\text { Regional } \\
\text { innovation } \\
\text { environment }\end{array}$} & \multirow{2}{*}{$\begin{array}{l}\text { Economic } \\
\text { basis }\end{array}$} & Per Capita GDP & $\begin{array}{l}10 \\
\text { thousand yuan }\end{array}$ & $Z_{13}$ & + \\
\hline & & Government revenue & $\begin{array}{l}100 \\
\text { million yuan }\end{array}$ & $Z_{14}$ & + \\
\hline & \multirow{3}{*}{$\begin{array}{l}\text { Innovation } \\
\text { incentives }\end{array}$} & $\begin{array}{l}\text { Enterprise R\&D } \\
\text { comes from } \\
\text { government funds }\end{array}$ & $\begin{array}{l}100 \\
\text { million yuan }\end{array}$ & $Z_{15}$ & + \\
\hline & & $\begin{array}{l}\text { Intramural expenditures } \\
\text { on } R \& D \text { in higher } \\
\text { education comes from } \\
\text { government funds }\end{array}$ & $\begin{array}{l}100 \\
\text { million yuan }\end{array}$ & $Z_{16}$ & + \\
\hline & & $\begin{array}{l}\text { Intramural expenditure } \\
\text { on } \mathrm{R} \& \mathrm{D} \text { of } \mathrm{R} \& \mathrm{D} \\
\text { institutions comes from } \\
\text { government funds }\end{array}$ & $\begin{array}{l}100 \\
\text { million yuan }\end{array}$ & $Z_{17}$ & + \\
\hline & \multirow[t]{2}{*}{ Livability } & $\begin{array}{l}\text { Per capita area } \\
\text { of parks and green land }\end{array}$ & sq.m & $Z_{18}$ & + \\
\hline & & $\begin{array}{l}\text { Per capita emissions } \\
\text { of main pollutant } \\
\text { contents discharged }\end{array}$ & tons & $Z_{19}$ & + \\
\hline & \multirow[t]{2}{*}{$\begin{array}{l}\text { Openness } \\
\text { level }\end{array}$} & $\begin{array}{l}\text { International trade } \\
\text { in goods }\end{array}$ & trillion yuan & $Z_{20}$ & + \\
\hline & & $\begin{array}{l}\text { Total amount } \\
\text { of foreign investment } \\
\text { actually utilized }\end{array}$ & $\begin{array}{l}\text { USD } \\
100 \text { million }\end{array}$ & $Z_{21}$ & + \\
\hline & \multirow{3}{*}{$\begin{array}{l}\text { Social } \\
\text { welfare }\end{array}$} & $\begin{array}{l}\text { The number of } \\
\text { health care institutes }\end{array}$ & unit & $Z_{22}$ & + \\
\hline & & $\begin{array}{l}\text { Collections of public } \\
\text { libraries per person }\end{array}$ & copy & $Z_{23}$ & + \\
\hline & & $\begin{array}{l}\text { Expenditure for } \\
\text { education in the general } \\
\text { public expenditure } \\
\text { of the government }\end{array}$ & $\begin{array}{l}100 \\
\text { million yuan }\end{array}$ & $Z_{24}$ & + \\
\hline
\end{tabular}


Table 1 (continued)

\begin{tabular}{|c|c|c|c|c|c|}
\hline $\begin{array}{l}\text { First } \\
\text { order index }\end{array}$ & $\begin{array}{l}\text { Second } \\
\text { order index }\end{array}$ & $\begin{array}{l}\text { Third } \\
\text { order index }\end{array}$ & Unit & Code & Type \\
\hline \multirow{4}{*}{$\begin{array}{l}\text { Regional } \\
\text { innovation } \\
\text { effectiveness }\end{array}$} & \multirow[t]{2}{*}{$\begin{array}{c}\text { Economic } \\
\text { benefit }\end{array}$} & Social labor productivity & $\begin{array}{l}100 \\
\text { million yuan }\end{array}$ & $Z_{25}$ & + \\
\hline & & GDP per unit area & $\begin{array}{l}10 \text { thousand } \\
\text { yuan } / \mathrm{mu}\end{array}$ & $Z_{26}$ & + \\
\hline & $\begin{array}{l}\text { People's } \\
\text { living conditions }\end{array}$ & $\begin{array}{l}\text { Per capita disposable } \\
\text { income of household }\end{array}$ & yuan & $Z_{27}$ & + \\
\hline & $\begin{array}{l}\text { Ecological } \\
\text { environment }\end{array}$ & $\begin{array}{l}\text { Energy intensity } \\
\text { of GDP }\end{array}$ & $\begin{array}{l}\text { tce } / 10000 \\
\text { yuan }\end{array}$ & $Z_{28}$ & + \\
\hline
\end{tabular}

\subsection{Sources of Data}

This paper uses the relevant data of ten provinces and cities in eastern China from 2014 to 2019 to measure the development status and trend of regional innovation capacity in eastern China from the perspective of high-quality development. The ten provinces and cities evaluated in this paper are Beijing, Tianjin, Hebei, Shanghai, Jiangsu, Zhejiang, Fujian, Shandong, Guangdong and Hainan. The relevant data of evaluation index are selected from China Statistical Yearbook, China Statistical Yearbook on Science and Technology, China Labor Statistical Yearbook, China Torch Statistical Yearbook and Statistical Yearbooks of various provinces and cities. In order to facilitate the comparison between different attributes, a global improved normalization $\operatorname{method}^{[35]}$ is used for dimensionless processing of the original data, and the cost-based indicators are converted into benefit-based indicators. Moreover, the entropy weight method is used to assign weights to indicators of different attributes to avoid errors caused by the subjective preferences of decision makers.

\section{Dynamic Evaluation Method Based on Gray Correlation Degree and TOPSIS}

The dynamic evaluation method based on TOPSIS and Grey correlation degree proposed by $\mathrm{Wu}$, et al. ${ }^{[31]}$ is used to assess the innovation capabilities of eastern China from the perspective of high-quality development. However, due to the original relative closeness have some deficiencies that relative closeness cannot ensure that the distance and similarity of the curve change between alternatives and ideal solutions are optimal, simultaneously. Therefore, the relative closeness that reflects the index difference degree is improved as follows:

$$
\begin{aligned}
& C_{i}^{d}\left(t_{k}\right)=\frac{D_{i}^{-}\left(t_{k}\right)}{D_{i}^{-}\left(t_{k}\right)+D_{i}^{+}\left(t_{k}\right)}, \quad i=1,2, \cdots, m, \quad j=1,2, \cdots, n, \quad k=1,2, \cdots, N, \\
& C_{i}^{r}\left(t_{k}\right)=\frac{R_{i}^{-}\left(t_{k}\right)}{R_{i}^{-}\left(t_{k}\right)+R_{i}^{+}\left(t_{k}\right)}, \quad i=1,2, \cdots, m, \quad j=1,2, \cdots, n, \quad k=1,2, \cdots, N, \\
& C_{i}\left(t_{k}\right)=\alpha C_{i}^{d}\left(t_{k}\right)+\beta C_{i}^{r}\left(t_{k}\right),
\end{aligned}
$$


where $C_{i}^{d}\left(t_{k}\right)$ is the relative closeness based on distance measure; $C_{i}^{r}\left(t_{k}\right)$ denotes the relative closeness based on the similarity of the curve change. $C_{i}\left(t_{k}\right)$ is the improved relative closeness, $\alpha$ indicates the preference to distance measure of decision maker, $\beta$ indicates the preference to the similarity of the curve change of decision maker. It takes $\alpha=\beta=0.5$ in this paper.

Similarly, the relative closeness values $\Delta C_{i}^{d}\left(t_{k}\right), \Delta C_{i}^{r}\left(t_{k}\right)$ and $\Delta C_{i}\left(t_{k}\right)$, which reflect the index growth degree, are able to be obtained using formulations (3.1) (3.3).

In order to obtain the evaluation results that take the difference degree and growth degree of evaluated objective into account simultaneously, $u_{i}\left(t_{k}\right)$ is calculated as follow:

$$
u_{i}\left(t_{k}\right)=\gamma C_{i}\left(t_{k}\right)+(1-\gamma) \Delta C_{i}\left(t_{k}\right)
$$

where $u_{i}\left(t_{k}\right)$ is the comprehensive evaluation value. $\gamma$ indicates the preference of decision makers for the degree of index difference and growth degree, the larger $\gamma$ indicates that the decision maker pays more attention to the degree of index difference, and $\gamma \in[0,1]$.

Finally, to solve the problem of inconsistent ranking of every year, the time weights ${ }^{[35]}$ are used to aggregate evaluation values of each year into a dynamic comprehensive evaluation values (time weights are determined by the model of time function which implies laying more stress on the present information than that on the past $\left.{ }^{[35]}\right)$. The calculation steps are as follows:

$$
\begin{aligned}
\omega_{k} & =\frac{\lambda_{k}}{\sum_{i=1}^{m}}, \quad k=1,2, \cdots, N, \\
\lambda_{k} & =\exp \left(-\frac{(k-N)^{2}}{2}\right), \quad k=1,2, \cdots, N, \\
\varphi_{i} & =\sum_{N}^{k=1} \omega_{k} u_{i}\left(t_{k}\right), \quad i=1,2, \cdots, m,
\end{aligned}
$$

where $\omega_{k}$ is time weight, $\varphi_{i}$ represents the dynamic comprehensive evaluation value within a period of time. According to the value $\varphi_{i}$, the evaluation objects can be evaluated and ranked, and it is convenient for decision-makers to make decisions.

The evaluation method used in this paper is the same as the method proposed by $\mathrm{Wu}$, et al. ${ }^{[31]}$ except for the calculation of relative closeness $\left(C_{i}\left(t_{k}\right)\right.$ and $\left.\Delta C_{i}\left(t_{k}\right)\right)$ and dynamic comprehensive evaluation value $\left(\varphi_{i}\right)$.

\section{Empirical Analysis of Regional Innovation Capability from the Per- spective of High-quality Development in Eastern China}

According to the evaluation index system, ten provinces and cities in the eastern region of China are selected as evaluated objectives, and their regional innovation capability is dynamically and comprehensively evaluated.

\subsection{Evaluation Results}

According to the modified method in Section 3, the regional innovation capability of the ten eastern provinces and cities from a high-quality perspective are evaluated, and the evaluation values and rankings can be obtained. The evaluation results are shown in Tables $2 \sim 7$.

Tables $2 \sim 4$ reflect the comprehensive evaluation results of regional innovation capability from the perspective of high-quality development. Table 2 shows that when $\lambda=1$, only the 
difference of each index value is considered, that is, the evaluation value and ranking of the difference in the development status of each evaluated object each year. Table 3 shows that when $\lambda=0$, only the growth degree of each index is considered, that is, the evaluation value and ranking of the annual development trend of each evaluated object. When $\lambda=0.8$ in Table 4 , it means that the differences and growth of the indicators are considered simultaneously, that is, it not only considers the development status of each evaluated object but also reflects the growth degree of each evaluated object, but focuses more on the development status of each year. And the last two columns of Table 4 are the dynamic comprehensive evaluation values and rankings that combine the evaluation values of each year by using time weights.

Table 2 Comprehensive evaluation results and rankings $(\gamma=1)$

\begin{tabular}{lcccccc}
\hline \multirow{2}{*}{ Provinces } & \multicolumn{5}{c}{ Evaluation values and ranking } \\
\cline { 2 - 6 } & 2014 & 2015 & 2016 & 2017 & 2018 & 2019 \\
\hline Beijing & $0.552(2)$ & $0.547(2)$ & $0.587(1)$ & $0.578(1)$ & $0.512(2)$ & $0.475(2)$ \\
Tianjin & $0.305(9)$ & $0.310(9)$ & $0.301(7)$ & $0.297(7)$ & $0.322(7)$ & $0.283(9)$ \\
Hebei & $0.451(5)$ & $0.452(5)$ & $0.280(8)$ & $0.283(8)$ & $0.300(8)$ & $0.413(4)$ \\
Shanghai & $0.421(6)$ & $0.421(6)$ & $0.407(3)$ & $0.415(4)$ & $0.407(4)$ & $0.392(6)$ \\
Jiangsu & $0.561(1)$ & $0.564(1)$ & $0.429(2)$ & $0.437(3)$ & $0.431(3)$ & $0.412(5)$ \\
Zhejiang & $0.394(7)$ & $0.404(7)$ & $0.341(5)$ & $0.354(5)$ & $0.359(5)$ & $0.371(7)$ \\
Fujian & $0.328(8)$ & $0.333(8)$ & $0.262(9)$ & $0.265(9)$ & $0.280(9)$ & $0.311(8)$ \\
Shandong & $0.496(3)$ & $0.492(3)$ & $0.317(6)$ & $0.329(6)$ & $0.332(6)$ & $0.424(3)$ \\
Guangdong & $0.462(4)$ & $0.486(4)$ & $0.393(4)$ & $0.456(2)$ & $0.514(1)$ & $0.532(1)$ \\
Hainan & $0.240(10)$ & $0.239(10)$ & $0.233(10)$ & $0.230(10)$ & $0.250(10)$ & $0.250(10)$ \\
\hline
\end{tabular}

Table 3 Comprehensive evaluation results and rankings $(\gamma=0)$

\begin{tabular}{lcccccc}
\hline \multirow{2}{*}{ Provinces } & \multicolumn{5}{c}{ Evaluation values and ranking } \\
\cline { 2 - 7 } & 2014 & 2015 & 2016 & 2017 & 2018 & 2019 \\
\hline Beijing & $0.528(2)$ & $0.453(4)$ & $0.327(5)$ & $0.388(3)$ & $0.464(8)$ & $0.394(6)$ \\
Tianjin & $0.450(5)$ & $0.420(7)$ & $0.282(10)$ & $0.288(10)$ & $0.706(2)$ & $0.297(10)$ \\
Hebei & $0.369(10)$ & $0.353(8)$ & $0.384(4)$ & $0.337(7)$ & $0.550(6)$ & $0.585(1)$ \\
Shanghai & $0.459(4)$ & $0.424(6)$ & $0.324(7)$ & $0.349(5)$ & $0.583(4)$ & $0.362(8)$ \\
Jiangsu & $0.693(1)$ & $0.497(2)$ & $0.409(3)$ & $0.344(6)$ & $0.440(10)$ & $0.427(5)$ \\
Zhejiang & $0.387(9)$ & $.475(3)$ & $0.420(2)$ & $0.356(4)$ & $0.580(5)$ & $0.437(4)$ \\
Fujian & $0.431(6)$ & $0.436(5)$ & $0.326(6)$ & $0.329(8)$ & $0.669(3)$ & $0.385(7)$ \\
Shandong & $0.525(3)$ & $0.308(10)$ & $0.320(8)$ & $0.396(2)$ & $0.506(7)$ & $0.585(1)$ \\
Guangdong & $0.393(8)$ & $0.706(1)$ & $0.731(1)$ & $0.661(1)$ & $0.448(9)$ & $0.561(3)$ \\
Hainan & $0.406(7)$ & $0.326(9)$ & $0.289(9)$ & $0.309(9)$ & $0.762(1)$ & $0.305(9)$ \\
\hline
\end{tabular}


Table 4 Comprehensive evaluation results and rankings $(\gamma=0.8)$

\begin{tabular}{|c|c|c|c|c|c|c|c|}
\hline \multirow{2}{*}{ Provinces } & \multicolumn{6}{|c|}{ Evaluation values and ranking } & \multirow{2}{*}{$\varphi_{i}$} \\
\hline & 2014 & 2015 & 2016 & 2017 & 2018 & 2019 & \\
\hline Beijing & $0.547(2)$ & $0.528(3)$ & $0.535(1)$ & $0.540(1)$ & $0.502(1)$ & $0.459(2)$ & $0.537(1)$ \\
\hline Tianjin & $0.334(9)$ & $0.332(9)$ & $0.297(8)$ & $0.295(7)$ & $0.399(6)$ & $0.286(9)$ & $0.299(8)$ \\
\hline Hebei & $0.435(5)$ & $0.432(5)$ & $0.301(7)$ & $0.294(8)$ & $0.350(10)$ & $0.447(4)$ & $0.308(7)$ \\
\hline Shanghai & $0.429(6)$ & $0.422(6)$ & $0.390(4)$ & $0.402(3)$ & $0.442(3)$ & $0.386(6)$ & $0.400(4)$ \\
\hline Jiangsu & $0.587(1)$ & $0.551(1)$ & $0.425(3)$ & $0.418(3)$ & $0.433(4)$ & $0.415(5)$ & $0.432(3)$ \\
\hline Zhejiang & $0.393(7)$ & $0.418(7)$ & $0.357(5)$ & $0.354(5)$ & $0.403(5)$ & $0.384(7)$ & $0.360(5)$ \\
\hline Fujian & $0.349(8)$ & $0.354(8)$ & $0.275(9)$ & $0.278(9)$ & $0.358(8)$ & $0.326(8)$ & $0.283(9)$ \\
\hline Shandong & $0.502(3)$ & $0.455(4)$ & $0.318(6)$ & $0.342(6)$ & $0.367(7)$ & $0.456(3)$ & $0.344(6)$ \\
\hline Guangdong & $0.448(4)$ & $0.530(2)$ & $0.461(2)$ & $0.497(2)$ & $0.501(2)$ & $0.538(1)$ & $0.487(2)$ \\
\hline Hainan & $0.273(10)$ & $0.256(10)$ & $0.244(10)$ & $0.246(9)$ & $0.352(9)$ & $0.261(10)$ & $0.246(10)$ \\
\hline
\end{tabular}

Table 5 to Table 7 is the sub-item evaluation results and rankings of the four different dimensions of regional innovation capability from the perspective of high-quality development. Table 5 shows the evaluation value when only the development status of each evaluated object $(\gamma=1)$ is considered, and the evaluation value of each year is twice weighted with the time weight. Table 6 shows the sub-item evaluation value when only the growth trend of each evaluated object is taken into account $(\gamma=0)$. Table 7 shows the sub-item evaluation value when the development status and growth degree of each evaluated object are considered at the same time $(\gamma=0.8)$.

Table 5 Sub-item evaluation results and rankings $(\gamma=1)$

\begin{tabular}{lcccc}
\hline Provinces & $\begin{array}{c}\text { Innovation } \\
\text { input }\end{array}$ & $\begin{array}{c}\text { Innovation } \\
\text { output }\end{array}$ & $\begin{array}{c}\text { Innovation } \\
\text { environment }\end{array}$ & $\begin{array}{c}\text { Innovation } \\
\text { effectiveness }\end{array}$ \\
\hline Beijing & $0.360(4)$ & $0.669(1)$ & $0.467(2)$ & $0.431(2)$ \\
Tianjin & $0.291(9)$ & $0.325(7)$ & $0.296(9)$ & $0.365(3)$ \\
Hebei & $0.304(8)$ & $0.308(8)$ & $0.426(4)$ & $0.257(9)$ \\
Shanghai & $0.340(6)$ & $0.385(4)$ & $0.388(6)$ & $0.750(1)$ \\
Jiangsu & $0.657(2)$ & $0.398(3)$ & $0.395(5)$ & $0.333(4)$ \\
Zhejiang & $0.523(3)$ & $0.366(5)$ & $0.369(7)$ & $0.296(5)$ \\
Fujian & $0.312(7)$ & $0.299(9)$ & $0.338(8)$ & $0.269(8)$ \\
Shandong & $0.358(5)$ & $0.365(6)$ & $0.435(3)$ & $0.281(7)$ \\
Guangdong & $0.732(1)$ & $0.428(2)$ & $0.570(1)$ & $0.292(6)$ \\
Hainan & $0.249(10)$ & $0.247(10)$ & $0.250(10)$ & $0.252(10)$ \\
\hline
\end{tabular}


Table 6 Sub-item evaluation results and rankings $(\gamma=0)$

\begin{tabular}{lcccc}
\hline Provinces & $\begin{array}{c}\text { Innovation } \\
\text { input }\end{array}$ & $\begin{array}{c}\text { Innovation } \\
\text { output }\end{array}$ & $\begin{array}{c}\text { Innovation } \\
\text { environment }\end{array}$ & $\begin{array}{c}\text { Innovation } \\
\text { effectiveness }\end{array}$ \\
\hline Beijing & $0.434(9)$ & $0.545(2)$ & $0.487(4)$ & $0.519(2)$ \\
Tianjin & $0.446(6)$ & $0.513(5)$ & $0.434(10)$ & $0.359(6)$ \\
Hebei & $0.496(3)$ & $0.502(7)$ & $0.502(2)$ & $0.327(10)$ \\
Shanghai & $0.441(8)$ & $0.455(9)$ & $0.471(6)$ & $0.749(1)$ \\
Jiangsu & $0.402(10)$ & $0.448(10)$ & $0.468(7)$ & $0.399(3)$ \\
Zhejiang & $0.577(1)$ & $0.516(4)$ & $0.475(5)$ & $0.390(4)$ \\
Fujian & $0.463(4)$ & $0.511(6)$ & $0.456(8)$ & $0.353(7)$ \\
Shandong & $0.446(6)$ & $0.498(8)$ & $0.500(3)$ & $0.340(8)$ \\
Guangdong & $0.574(2)$ & $0.550(1)$ & $0.517(1)$ & $0.371(5)$ \\
Hainan & $0.458(5)$ & $0.524(3)$ & $0.452(9)$ & $0.329(9)$ \\
\hline
\end{tabular}

Table 7 Sub-item evaluation results and rankings $(\gamma=0.8)$

\begin{tabular}{lcccc}
\hline Provinces & $\begin{array}{c}\text { Innovation } \\
\text { input }\end{array}$ & $\begin{array}{c}\text { Innovation } \\
\text { output }\end{array}$ & $\begin{array}{c}\text { Innovation } \\
\text { environment }\end{array}$ & $\begin{array}{c}\text { Innovation } \\
\text { effectiveness }\end{array}$ \\
\hline Beijing & $0.374(5)$ & $0.644(1)$ & $0.471(2)$ & $0.448(2)$ \\
Tianjin & $0.322(9)$ & $0.363(7)$ & $0.324(9)$ & $0.364(3)$ \\
Hebei & $0.342(7)$ & $0.347(8)$ & $0.441(4)$ & $0.271(9)$ \\
Shanghai & $0.361(6)$ & $0.399(4)$ & $0.405(6)$ & $0.749(1)$ \\
Jiangsu & $0.606(2)$ & $0.408(3)$ & $0.410(5)$ & $0.346(4)$ \\
Zhejiang & $0.534(3)$ & $0.396(5)$ & $0.390(7)$ & $0.314(5)$ \\
Fujian & $0.342(7)$ & $0.342(9)$ & $0.362(8)$ & $0.286(8)$ \\
Shandong & $0.376(4)$ & $0.391(6)$ & $0.448(3)$ & $0.293(7)$ \\
Guangdong & $0.7(1)$ & $0.453(2)$ & $0.559(1)$ & $0.307(6)$ \\
Hainan & $0.291(10)$ & $0.302(10)$ & $0.290(10)$ & $0.267(10)$ \\
\hline
\end{tabular}

\subsection{Analysis of the Overall Regional Innovation Capability from a High-quality Perspective}

In order to fully understand the comprehensive development status of the regional innovation capability of the eastern provinces and cities from the high-quality perspective, this article presents the development status and growth degree of the provincial innovation capability. The specific evaluation results are shown in Tables $2 \sim 4$.

On the whole, from high-quality perspective, Jiangsu, Zhejiang, Shanghai, and Guangdong provinces have strong innovation capabilities, but the development of innovation capabilities in the Beijing-Tianjin-Hebei region is unbalanced, and the regional innovation capability of Fujian, Shandong, and Hainan is at the middle and lower reaches of the level. Jiangsu, Zhejiang, Shanghai, and Guangdong have gradually established coordinated and integrated regional inno- 
vation cooperation and sharing mechanism, and using their geographical proximity, innovation resources have been integrated across regions. In addition, regional governments strive to create an open and inclusive innovation environment conducive to stimulating the vitality of innovation subjects. The innovation results obtained in different regions spread and overflow, to achieve the sharing of innovation results, thereby promoting inter-regional industrial upgrading, promoting the conversion of new and old development driving force, carrying out environmentally friendly development, so that the people have more sense of gain and happiness.

There are big differences in the innovation capabilities of the Beijing-Tianjin-Hebei region, and its internal development is relatively unbalanced. The regional innovation capability of Beijing and Tianjin from a high-quality perspective will be better than that of Hebei. Moreover, as the capital of Beijing, the siphon effect on Tianjin and Hebei is still obvious. A large amount of resources such as cutting-edge talents and capital have gathered in Beijing, resulting in relatively insufficient innovation resources in Tianjin and Hebei, which in turn affects the regional innovation capability of Tianjin and Hebei. In Fujian and Hainan, due to the massive loss of talents and other innovation element resources, the innovation ability of regional innovation entities has been significantly reduced. In addition, the lack of an innovation environment that encourages the vitality of innovation entities has caused the existing innovation resources to not be effectively transformed into innovation output and improve the quality of development, restricting the effectiveness of regional innovation.

There are big differences in the innovation capabilities of the Beijing-Tianjin-Hebei region, and its internal development is relatively unbalanced. The regional innovation capability of Beijing and Tianjin from a high-quality perspective will be better than that of Hebei. Moreover, as the capital of Beijing, the siphon effect on Tianjin and Hebei is still obvious. A large amount of resources such as cutting-edge talents and capital have gathered in Beijing, resulting in relatively insufficient innovation resources in Tianjin and Hebei, which in turn affects the regional innovation capability of Tianjin and Hebei. In Fujian and Hainan, due to the massive loss of talents and other innovation element resources, the innovation ability of regional innovation entities has been significantly reduced. In addition, the lack of an innovation environment that encourages the vitality of innovation entities has caused the existing innovation resources to not be effectively transformed into innovation output and improve the quality of development, restricting the effectiveness of regional innovation.

Comprehensively considering the development status and growth degree of regional innovation capability from a high-quality perspective, Beijing, Jiangsu, Guangdong, and Shanghai are ranked in the top four. These regions have relatively rich innovation resource input and efficient innovation output. The environment has effectively stimulated the innovation vitality of innovative subjects, which has significantly improved social benefits, and the people's sense of gain and happiness have also been greatly improved. It shows that the allocation of innovation resources in these regions is relatively reasonable, and the upgrading of the industrial structure is relatively complete. Through the improvement of regional innovation capability, it has returned to the ultimate goal of development, which is to improve the economic quality and efficiency, and also make the people's sense of gain and happiness continue to increase, which makes the improvement of regional innovation capability more realistic. In contrast, 
Fujian, Hebei, Tianjin, and Hainan have weaker innovation capabilities. These areas are relatively deficient in innovation resources due to the siphon effect of Beijing, Jiangsu, Zhejiang, Shanghai, and Guangdong. At the same time, due to the poor innovation environment in these regions, their innovation capabilities are relatively low, which in turn affects their innovation effectiveness.

\subsection{Sub-Item Evaluation Analysis of Regional Innovation Ability from High-quality Development Perspective}

In order to have a deeper understanding of the development status and trends of various dimensions of the regional innovation capability of the ten eastern provinces and cities from highquality development perspective, this article analyzes the four dimensions of innovation input, innovation output, innovation environment and innovation effectiveness in various provinces and cities from 2014 to 2019. The specific results are shown in Table 5 to Table 7.

In the aspect of innovation resources input, there is a strong polarization among the provincial regions. Due to unique geographical advantages, better economic foundations, and good atmosphere for innovation and entrepreneurship, Guangdong and Zhejiang have a higher level of innovation input. As the nation's political, cultural and technological innovation center, Beijing enjoys more innovation and entrepreneurship policies and resources, attracting talents and funds from all over the country and even the world. Therefore, its annual innovation investment level is better than other regions. However, the surrounding areas, such as Tianjin and Hebei, have relatively insufficient resource elements. In addition, compared with other regions, Fujian and Hainan have weaker economic development, moreover, "the siphon effect" of Jiangsu, Zhejiang, Shanghai and Guangdong on talents and capital, making the level of innovation input in Fujian and Hainan at a lower level. Thus, it may affect their regional innovation capability.

In terms of innovation output, Beijing, Guangdong, and Jiangsu are ahead of other provinces and cities, and the development of the Beijing-Tianjin-Hebei region is not coordinated enough. From the perspective of development status, Beijing has the highest innovation efficiency, and its innovation output ranks first when the input of innovation resources is lower than that of regions such as Guangdong and Jiangsu. Guangdong ranks second. Fujian, Hainan and other regions have relatively weaker innovation output capabilities. From the perspective of growth degree, Beijing and Guangdong have the largest growth potential in terms of innovation output. To some extent, it shows that in recent years, Beijing and Guangdong have reasonable allocation of innovation factor resources, and the vitality of innovation entities has been effectively stimulated to promote the conversion of new and old power. Regional innovation output capacity is continuously improving, and it is turning to high-quality development. At the same time, Fujian and Hainan have relatively high growth levels and are in an upward period of catching up with other provinces and cities, indicating that these regions have increased their emphasis on innovation capabilities and achieved certain results. On the other hand, Tianjin, Hebei and other regions are limited by the relative lack of innovation resources, their innovation output will be relatively insufficient, and the development of the Beijing-Tianjin-Hebei region is uneven, and Beijing has not formed an effective radiation driving effect on Tianjin and Hebei.

In terms of innovation environment, compared with other provincial-level regions, Beijing, Shanghai, Jiangsu, and Guangdong have a better regional innovation environment. From the 
perspective of development status, the regional innovation environment of Beijing and Guangdong are in the forefront. The awareness of high-quality development in these regions is beeter than that of other regions, and they enjoy better infrastructure. Moreover, the government actively creates an environment conducive to innovation, and gives enterprises, universities, research institutions and other innovation entities sufficient policy incentives. Compared with Beijing, Shanghai and other regions, Fujian, Hainan and other regions have a poor innovation environment, because there are large gaps in economic foundation, innovation incentives, social welfare and cultural environment. And the attractiveness of high-end talents is relatively insufficient. At the same time, the economic development of these areas lags behind that of Beijing, Shanghai and Guangzhou. Therefore, in order to accelerate economic development, the local government may allocate resources such as policies and funds to projects with low risks, short cycles, and fast returns, thus restricting the improvement of the ability of regional innovation. From the perspective of growth degree, the gap between Beijing, Shanghai, Guangdong and Fujian, Hainan in terms of regional innovation environment has a trend of increasing. The development trend of Beijing, Shanghai and Guangzhou in terms of ecological environment, openness and innovation incentives grow faster than that of Fujian, Hebei and Hainan.

In terms of innovation effectiveness, the development effectiveness of Beijing, Shanghai and Tianjin is better than that of other regions. The development effectiveness of Guangdong Province does not match its innovation input, innovation output and innovation environment. It can be concluded from the evaluation results that Beijing, Shanghai, Tianjin have significantly better innovation performance than other regions. These provinces and cities have attracted a large number of knowledge-intensive enterprises and talents, creating a good innovation environment, and the resources of innovation elements are allocated reasonably. The knowledge output and technological output of these regions are in the forefront. And the people's living quality and the protection of ecological environment of these provinces are better than that of other regions. However, due to location conditions and economic base restrictions, the innovation effectiveness of Fujian, Hebei and Hainan are not significant. It shows that the high-quality development in these areas has not effectively improved economic benefits and improved people's living quality.

\section{Conclusions and Suggestions}

\subsection{Conclusions}

This paper clarifies the connotation of high-quality development based on the new development concept. From the perspective of high-quality development, regional innovation capability has richer connotations. Regional innovation capability is not only reflected in the input of innovation resources and the output of innovation, but also includes regional livability, social welfare and a good environment for innovation. And from the perspective of high-quality development, the improvement of regional innovation capability cannot be only represented by the increase in output in a narrow sense such as technological innovation and knowledge innovation. It should also reflect the ultimate goal of development, that is, the living quality of people has been improved a lot, the people's sense of gain and happiness has been enhanced, the ecological environment has been protected, and the social and economic benefits have been improved. 
Therefore, a regional innovation capability evaluation index system from the perspective of high-quality development is established, and the relative closeness of the dynamic evaluation method based on ideal solution and gray correlation degree ${ }^{[31]}$ is improved in this paper. The improved method is used to evaluate the regional innovation capability of ten eastern provinces and cities. Through this method, the evaluation value and ranking can be obtained considering the development status and growth degree of the evaluated object at the same time, so as to obtain a more comprehensive and accurate evaluation result. According to the analysis of the evaluation results, this article draws the following conclusions:

1) From the perspective of development status, the development of regional innovation capability from a high-quality perspective of various provinces is uneven. Beijing, Shanghai, Guangdong and Jiangsu have high regional innovation capability, but Fujian, Hebei and Hainan have weak regional innovation capability. There is polarization between different provinces and cities.

2) From the perspective of development trends, after turning to high-quality development in Fujian, Hebei, and Hainan, the regional innovation capability has gradually improved, and the gap with Beijing, Guangdong, Shanghai and Jiangsu has been shrinking.

3) Beijing, Guangdong and Jiangsu have relatively rich innovation resources, a more complete innovation environment, and a better innovation atmosphere. Therefore, they also perform better than other regions in terms of innovation output and innovation effectiveness. However, Fujian, Hebei, and Hainan have poor performance in four dimensions of evaluation index system due to the weaker factors such as location conditions and economic foundation.

\subsection{Suggestions}

First of all, for the regions with strong regional innovation capability from a high-quality perspective, such as Beijing, Shanghai, Guangdong, and Jiangsu, the reform of relevant systems and mechanisms should be actively promoted, do a good job in market guidance and supervision, and avoid duplication of innovation resources and blind investment. Transfer repeated innovation element resources and knowledge spillovers to neighboring areas, enhance the radiating and driving effect on surrounding areas, strengthen inter-regional innovation and collaboration, and promote inter-regional functional complementarity. At the same time, these regions should pay more attention to the harmonious development of man and nature and the quality of life of the people.

Secondly, for the regions such as Fujian, Hebei, and Hainan where the regional innovation capability is weaker from the perspective of high-quality development, innovation resources should be integrated, and policy support and financial subsidies for industries with backward production capacity should be gradually reduced to ensure innovation resources to be allocated effectively and reasonably. These regions should continue to encourage enterprises, universities and scientific research institutes and other innovation entities to carry out technological innovation. Moreover, the construction of intellectual property protection mechanisms should be improved in order to strive to create an innovation environment that is conducive to stimulating the innovation vitality of innovation entities. At the same time, it is necessary to continuously improve the talent introduction and training mechanism and to formulate a talent introduction system that meets the needs of the region's own development. In addition, the development of 
education in the region should be strengthened in order to cultivate innovative talents, so as to provide the continuous innovation vitality for the regional development. Finally, infrastructure construction should be strengthened continuously, social welfare should be improved, and the ecological environment must be protected, so as to create a livable environment that attracts talents and continuously improves the effectiveness of innovation.

\section{References}

[1] Ren B P, Miao X Y. The cultivation of the new economic momentum of China's high-quality development in the "14th Five-Year Plan". On Economic Problems, 2021, 2: 1-11+106.

[2] Zhou B, Zeng X Y, Lu J, et al. High-quality economic growth under the influence of technological innovation preference in China: A numerical simulation from the government financial perspective. Structural Change and Economic Dynamics, 2020, 54: 163-172.

[3] Peng W B, Yin Y, Kuang C, et al. Spatial spillover effect of green innovation on economic development quality in China: Evidence from a panel data of 270 prefecture-level and above cities. Sustainable Cities and Society. 2021, 69: 102863.

[4] Yang Y W, Zhang P. Logic, measurement and governance in China's high-quality economic development. Econimic Research Journal, 2021, 56(1): 26-42.

[5] Jin Q H, Yan T H. The dynamic threshold effect of OFDI on regional innovation ability. Science Research Management, 2019, 40(11): 58-66.

[6] Bian Y C, Wu L H, Bai J H. Does high-speed Rail improve regional innovation in China? Journal of Financial Research, 2019, 6: 132-149.

[7] Ye A Z, Chen X L. Impulse response analysis on FDI, innovation and economic growth in time and space. Systems Engineering — Theory \& Practice, 2017, 37(2): 353-364.

[8] Zhou Z B, Deng L, Xiao H L, et al. The impact of foreign direct investment on China's high-quality economic development - Index DEA and panel partition regression analysis. Chinese Journal of Management Science, 2020: 1-12. https://doi.org/10.16381/j.cnki.issn1003-207x.2019.1040.

[9] Min S J, Kim J, Sawng Y W. The effect of innovation network size and public R\&D investment on regional innovation efficiency. Technological Forecasting and Social Change, 2020, 155: 119998.

[10] Li X H, Sun L Y, Sun R T, et al. Transshipment profits Distribution considering the customer transfer and new product substitute. Journal of Industrial Engineering Management, 2010, 24(3): 1-6.

[11] Liu H D, Liu F F. The black box deconstruction of factor agglomeration promoting high and new technology industry performance - Analysis of threshold effect based on high-quality economic development. Studies in Science of Science, 2021, 39(11): 1960-1969.

[12] Chen J, Wang L J, Li Y Y. Natural resources, urbanization and regional innovation capabilities. Resources Policy, 2020, 66: 101643.

[13] Hyochul P, Timothy R A, Wonchul S. Regional innovation capability from a technology-oriented perspective: An analysis at industry level. Computers in Industry, 2021, 129: 103441.

[14] Pan X F, Guo S C, Li M N, et al. The effect of technology infrastructure investment on technological innovation - A study based on spatial durbin model. Technovation, 2021, 107: 102315.

[15] Yang X L, Zhang Y, Yang C H, et al. Research on the determinants of government investment effect. Journal of Systems Science and Information, 2020, 8(5): 387-400.

[16] Li M J, Wei Y K, Xu L M. Dynamic evaluation and analysis on regional collaborative innovation capabilities based on gray target. Science of Science and Management of S.\&.T, 2017, 38(8): 122-132.

[17] Xie L L. Do industrial agglomeration and innovation incentives improve regional innovation efficiency? An empirical study of urban agglomerations in the Yangtze River Delta. Economist, 2019, 8: 102-112.

[18] Li Z, Yang S Y. Fiscal decentralization, government innovation preferences and regional innovation efficiency. Journal of Management World, 2018, 34(12): 29-42+110+193-194.

[19] Wang R Q. The empirical analysis about spatial correlation and diffusion impact in regional technological innovation - Based on 1997-2008's spatial panel data. Systems Engineering - Theory \& Practice, 2012, 32(11): 2419-2432.

[20] Pan W B, Huang L, Zhao L L. An integrated DEA model allowing decomposition of eco-efficiency: A case 
study of China. Journal of Systems Science and Information, 2017, 5(5): 473-488.

[21] Su Y, Li B Z. Regional innovation system performances based on stochastic frontier analysis. Journal of Systems Engineering, 2013, 28(1): 125-133.

[22] Su Y, Liu Y X. A literature review on the regional innovation research methods. Science Research Management, 2019, 40(9): 14-24.

[23] Yu L P, Liu J. Are principal component analysis and factor analysis suitable for scientific and technological evaluation? - Taking academic journals as an example. Journal of Modern Information, 2018, 38(6): $73-79+137$.

[24] Hwang C L, Yoon K. Multiple attribute decision making: Methods and application. Springer-Verlag, Berlin, 1981.

[25] Chen Y, Li W W, Yi P T. Evaluation of city innovation capability using the TOPSIS-based order relation method: The case of Liaoning province, China. Technology in Society, 2020, 63: 101330.

[26] Li M J, Yuan N, Chen L. Improved TOPSIS based on projective method and angle measure evaluation method. Journal of Systems Science and Mathematical Sciences, 2020, 40(9): 1614-1627.

[27] Li M J, Pan Y X, Xu L M, et al. Improved dynamic TOPSIS evaluation method of interval numbers. Journal of Systems Science and Mathematical Sciences, 2021, 41(7): 1891-1904.

[28] Jiang H, Lin J Y, Jiang P. Using grey relational analysis with entropy to predict the international financial center of China. Journal of Systems Science and Information, 2017, 5(1): 88-96.

[29] Hui G, Bifeng S. Study on effectiveness evaluation of weapon systems based on grey relational analysis and TOPSIS, Journal of Systems Engineering and Electronics, 2009, 20(1): 106-111.

[30] Yuan S Y, Sun X P, Chen W G, et al. Study on the measurement of industrial structure sophistication,rationalization and ecologicalization based on the dynamic analysis of grey relations a case study of Beijing-Tianjin-Hebei. Journal of Systems Science and Information, 2020, 8(2): 130-147.

[31] Wu F M, Li M J, Xu L M, et al. Dynamic evaluation method based on TOPSIS and gray correlation degree and its application. Chinese Journal of Management Science, 2019, 27(12): 136-142.

[32] Bai J H, Bian Y C. Does government support promote IUR synergy innovation. Statistical Research, 2015, 32(11): 43-50.

[33] Ma R, Luo H, Wang H W, et al. Study of evaluating high-quality economic development in Chinese regions. China Soft Science Magazine, 2019, 7: 60-67.

[34] Zhang K, Huang L Y. Study on the impact of introducing foreign capital on regional innovation capability. Soft Science, 2019, 33(8): 49-53.

[35] Yi P T, Zhou Y, Guo Y J, et al. A dynamic comprehensive evaluation method embodying development tendency. Operations Research and Management Science, 2016, 25(6): 175-180. 